\title{
The Consequence Of International Law Of Children Appointment In Indonesia
}

\author{
Bernard Nainggolan \\ Postgraduate of Law \\ Universitas Kristen Indonesia, Jakarta, Indonesia \\ Hulman Panjaitan \\ Faculty of Law \\ Universitas Kristen Indonesia, Jakarta, Indonesia
}

\begin{abstract}
The adoption of children is nothing new in Indonesian society, including the adoption of international children, more specifically the adoption of children carried out by foreign citizens of Indonesian citizens. In practice, international appointments cause many legal problems, especially those related to the legal consequences. In this study normative juridical legal research methods are used with qualitative data analysis, which analyzes the data of the brother through existing legal materials based on applicable laws and regulations. At least as a result of international child adoption law, relating to aspects of citizenship, marriage guardianship and inheritance.
\end{abstract}

Keywords: intercountry adoption, domestic adoption, adoption law.

\section{INTRODUCTION}

Children are the gift of God Almighty who is an asset of the nation and the descendants of the family (generation) In social life, not all husband or wife couples are blessed with children as a result of marriage, so various ways are taken to get offspring, one of which is through the adoption of children or adoption as an act by taking other people's children who are not his offspring to be cared for and treated as a child himself.

Initially the main purpose of adoption is solely to continue the descent. However, in subsequent developments these goals have changed and shifted in the interests of the child, which according to the laws and regulations is in the best interest of the child in the context of realizing child welfare and child protection.

In Indonesia itself, adoption institutions are not new. Because this institution has been known for a long time in indigenous communities. Muderis Zaini argues that for heterogeneous Indonesians, which consist of various tribes and races, they have long known that there are institutions of adoption with names or terms that differ from one tribe to another. Even though it must be admitted that normatively, the appointment of adoption of new children has existed since the enactment of Stb Number 129 of 1917 concerning the adoption of children specifically for the Chinese community or class. 
In general, the adoption of children can be grouped into the adoption of children between Indonesian citizens and the adoption of children between Indonesian citizens and foreign citizens. The first type is known as the adoption of domestic children (domestic adoption) and for the second type known as international adoption of children (intercountry adoption).

As a legal act, the adoption of both domestic and international adoption of children will result in legal consequences from various aspects of life, especially for adopted children. In practice, it is found that there are various legal issues that not infrequently have to lead to court. Therefore it is felt necessary to study and examine the appointment of international children, especially related to the legal consequences.

\section{RESEARCH METHODS}

The form of this research is normative legal research or doctrinal legal research aimed at and relating to an inventory of legal principles or principles, research on the application of the law, both those that operate operationally by institutions and in terms of legal settlement procedures in practice. The data used are secondary data obtained based on documentary studies or literature in the form of primary, secondary and tertiary legal law. Secondary data in the form of three types of legal materials are processed in such a way through qualitative data analysis.

\section{THEORETICAL BASIS}

Etymologically, adoption comes from the Dutch language, which is "adoptie" or which in English is "adopt" and in Latin is "adoptio". According to the Big Indonesian Dictionary, adoption is the adoption of another person's child as his own child. While adopting is taking (adopting) someone else's child legally into his own child.

In perspective, doctrine, according to R. Supomo, that adoption is to take a child, take a child, adopt a child is a legal action within the framework of customary ancestral law, when a child is appointed or occupied and accepted in a position, both biological and social, which all there is nothing to him.

Authentically through Article 1 number (2) PP No. 54 of 2007 concerning Implementation of Adoption of Children formulates the definition of adoption of a child as a legal act that diverts a child from the environment of the authority of parents, legal guardians or others who are responsible for the care, education, and raising of the child into the family environment of adoptive parents.

Various reasons or motives behind the adoption of children. There is because of mercy, then because it does not have children so it is a provocation, including to continue the descent. Apart from the background and purpose of adoption as described above, a number of laws and regulations have governed and determined that concerning adoption, the most important thing is to pay attention to the best interests of the child.

In general, adoption of children can be grouped into 2 (two) parts, namely Appointment of Domestic Children (domestic adoption), which is carried out between Indonesian citizens and International or International Appointment of Children (intercountry adoption), which is carried out between Indonesian citizens with foreign nationals. This classification is also regulated in PP No. 54 of 2007 which distinguishes adoption into:

a. Appointment of Children between Indonesian citizens; 
Nainggolan, B. \& Panjaitan, H. (2020). The Consequence of International Law of Children Appointment in Indonesia. Advances_in Social Sciences Research Journal, 7(4) 102-106.

b. Appointment of Children between Indonesian citizens and foreign nationals.

Furthermore, for adoption of Children between Indonesian citizens and foreign nationals, including: a. Appointment of Indonesian children by foreign citizens; and b. Appointment of children of foreign nationals in Indonesia by Indonesian citizens.

\section{DISCUSSION ANALYSIS}

As a legal act, the adoption of children (international or intercountry adoption) brings legal consequences in various aspects of the adopted child's life, which in broad outline, can be described as a result of the relevant international adoption law in 3 (three) cases, namely:

\section{Legal consequences of citizenship}

In the act of adopting international children, especially adoption of children carried out by foreigners on adopted children of Indonesian citizens, the legal consequence is that the adopted child will have two (dual) citizenship. In article 5 paragraph (2) of Law no. 12 of 2006 has been determined as a result of the law of the appointment of international children, namely children of Indonesian citizens who have not aged 5 (five) years were legally appointed as children by Indonesian citizens based on the determination of the court still recognized as Indonesian citizens. For this, Article 6 stipulates that in the case of RI's citizenship status towards children, the child will have dual citizenship, so after the child is 18 (eighteen) years old or has married, he must declare to choose one of his citizenship.

\section{Marriage Guardian}

According to Islamic law, a marriage guardian in marriage is a pillar that must be fulfilled for the bride who acts to carry it out. It was determined that the right to be the guardian of marriage is a man who fulfills the requirements of Islamic law, namely Muslims, puberty and baligh. In connection with the appointment of international children, since the verdict or stipulation is pronounced in court, then the rights and obligations of biological parents shift to adoptive parents, except for adoptive parents who are Muslim, then prospective adoptive parents are not entitled to become marriage guardians at the time his daughter will get married, because for that what can become a marriage guardian is a biological parent or blood relatives. Therefore, adoptive parents must notify adopted children of biological parents and their origins.

\section{Inheritance}

In Indonesia, there are differences in the regulation of inheritance rights between customary law, Islamic law and jurisprudence. In particular, there are no regulations governing the status and inheritance rights of adopted Indonesian citizens who are appointed by foreigners. However, based on a court decision or jurisprudence, we will find out which legal inheritance system is used. For this reason, it can be described in principle as follows:

\section{Decision of the District Court}

Appointment of children obtained based on the determination or decision of the District Court, the adopted child is recognized as the heir of his adoptive parents. Such legal consequences are regulated in Articles 11 and 12 Stb 1917 No. 129. 


\section{Determination/decision of the Religious Court.}

In accordance with the provisions of Islamic law, the status of adopted children in the case of inheritance is that the adopted child remains the heir of his biological parents, but the person concerned can be given a gift or will not be able to exceed the legitimate portie inheritance rights that cannot be more than $1 / 3$ (one third) of inheritance.

There are various court decisions as jurisprudence relating to the legal consequences of the adoption of children in the field of inheritance, namely:

a. MARI Decision No. 182 K / Sip / 1959 dated July 15, 1959 which contained the rule of law that adopted children had the right to inherit the inheritance of their adoptive parents who were not inherited from the adoptive parents.P

b. MARI Decision No. 27 K / Sip / 1959 dated March 18, 1959, which contained the rule of law that according to the laws in force in Central Java, adopted children were only allowed to inherit gono gini [ assets that were collected during the marriage so that it becomes the right of both husband and wife] assets from their adopted parents, so on heirlooms (originated goods), adopted children had no right to inherit it

c. MARI Decision No. 516 K / Sip / 1968 dated January 4, 1969 which contained the rule of law that according to customary law in force in the area of East Sumatra, adopted children do not have the right to inherit the inheritance of their adopted parents. He can only get gifts or grants from adoptive parents while living.

d. MARI Decision No. 82 K / Sip / 1958 dated May 24, 1958 which contained the rule of law that the kukut child (adopted child) had no right to inherit heirlooms, these items returned to the heirs of blood.

e. MARI Decision No. 1278 K / Sip / 1977 dated March 3, 1981 which contains the rule of law that because the adoption of a child determined by the court is never revoked, the adopted child has the right to inherit.

\section{CONCLUSION}

In the legal perspective in Indonesia, due to international adoption law, especially the appointment of Indonesian citizens by Foreign Citizens, there are at least 3 (three) aspects, namely aspects of citizenship, aspects of marriage guardianship and inheritance aspects. For the aspect of citizenship, with the adoption of children of different countries (intercountry adoption), the children of Indonesian citizens who are appointed by foreign citizens before the age of 18 (eighteen) years are still citizens of Indonesia, but after the age of 18 (eighteen) years or already married, the adopted child can choose his citizenship, whether to remain a citizen of Indonesia or follow the foster parent's citizenship. For marriage guardians, this still follows the conditions in Islamic law which stipulate that the rightful and authorized to be marriage guardians are biological parents or those who have blood ties with the adopted child concerned. As for the matter of inheritance, it depends on the inheritance law that applies to the adoptive parents of the Foreign Citizen.

To achieve the purpose of adoption, including the international adoption of children under the law, in the best interests of the child and his welfare, the adoption of legal acts must be carried out in 
Nainggolan, B. \& Panjaitan, H. (2020). The Consequence of International Law of Children Appointment in Indonesia. Advances_in Social Sciences Research Journal, 7(4) 102-106.

such a way according to the terms and procedures set out in the applicable laws and regulations, no exception to the appointment international children (intercountry adoption).

\section{References}

\section{Books}

1. Abdurrahman H, Kompilasi Hukum Islam di Indonesia, Akademi Pressindo, Jakarta, 2004.

2. Ahmad H. Kamil, Hukum Perlindungan dan Pengangkatan Anak di Indonesia, Rajawali Press, Jakarta, 2010.

3. Andi H. Syamsu Alam dan H. M. Fauzan, Hukum Pengangkatan Anak Persfektif Islam, Kencana, Jakarta, 2008.

4. Budiarto M, Pengangkatan Anak Ditinjau Dari Segi Hukum, Akademika Pressindo, Jakarta, 1991,

5. Gautama Sudargo, Hukum Perdata Internasional Indonesia, Buku Ketujuh Bagian Pertama, PT. Kinta, Jakarta, 1969.

6. --a------, Hukum Perdata Internasional Indonesia, Jilid III Bagian I, Alumni, Bandung, 1961.

7. Hadikusuma Hilman, Hukum Perkawinan Adat, PT. Citra Aditya Bakti, Bandung, 1990.

8. Panjaitan Hulman, Kumpulan Kaidah Hukum Putusan Mahkamah Agung Republik Indonesia Tahun 1953-2008 Bertdasarkan Pengggolongannya, Kencana, Jakarta, 2014.

9. Prodjodikoro Wirjono, Hukum Waris di Indonesia, Sumur Bandung, 1991.

10. Pusat Bahasa Departemen Pendidikan Nasional, Kamus Besar Bahasa Indonesia, Edisi Ketiga, Balai Pustaka, Jakarta, 2005.

11. S. Djaja Meliala, Pengangkatan Anak di Indonesia, Tarsito, Bandung, 1982.

12. Sembiring Rosnidar, Hukum Keluarga, Harta Benda Dalam Perkawinan, Rajgarfindo Persada, Jakarta, 2019

13. Soepomo R, Bab Bab Tentang Hukum Adat, Pradnya Paramita, Jakarta, 2003.

14. Tafal Bastian Tafal, Pengangkatan Anak Menurut Hukum Adat serta Akibat Akibat Hukumnya Dikemudian Hari, Rajawali Press, Jakarta, 1983.

15. Zaini Muderis, Adopsi, Suatu Tinjauan dari Tiga Sistem Hukum, Sinar Grafika, Jakarta, 1999.

\section{Legal Regulations}

1. Undang Undang Republik Indonesia Nomor 23 Tahun 2002 tentang Perlindungan Anak

2. Undang Undang Republik Indonesia Nomor 12 Tahun 2006 tentang Kewarganegaraan Republik Indonesia

3. Undang Undang Republik Indonesia Nomor 35 Tahun 2014 tentang Perubahan Undang Undang No. 23 Tahun 2002 tentang Perlindungan Anak.

4. Peraturan Pemerintah Nomor 54 Tahun 2007 tentang Pelaksanaan Pengangkatan Anak

5. Peraturan Menteri Sosial Republik Indonesia No. 110/HUK/2007 tentang Pelaksanaan Pengangkatan Anak tanggal 19 Oktober 2009. 